\title{
Reactivating the Ni-YSZ electrode in solid oxide cells and stacks by infiltration
}

Skafte, Theis Løye; Hjelm, Johan; Blennow Tullmar, Peter; Graves, Christopher R.

Published in:

Journal of Power Sources

Link to article, DOI:

10.1016/j.jpowsour.2018.01.021

Publication date:

2018

Document Version

Peer reviewed version

Link back to DTU Orbit

Citation (APA):

Skafte, T. L., Hjelm, J., Blennow Tullmar, P., \& Graves, C. R. (2018). Reactivating the Ni-YSZ electrode in solid oxide cells and stacks by infiltration. Journal of Power Sources, 378, 685-690.

https://doi.org/10.1016/j.jpowsour.2018.01.021

\section{General rights}

Copyright and moral rights for the publications made accessible in the public portal are retained by the authors and/or other copyright owners and it is a condition of accessing publications that users recognise and abide by the legal requirements associated with these rights.

- Users may download and print one copy of any publication from the public portal for the purpose of private study or research.

- You may not further distribute the material or use it for any profit-making activity or commercial gain

- You may freely distribute the URL identifying the publication in the public portal 


\title{
Reactivating the Ni-YSZ electrode in solid oxide cells and stacks by infiltration
}

\author{
Theis Løye Skafte ${ }^{\mathrm{a}, \mathrm{b}, *}$, Johan Hjelm ${ }^{\mathrm{b}}$, Peter Blennow ${ }^{\mathrm{a}}$, Christopher Graves ${ }^{\mathrm{b}}$ \\ ${ }^{a}$ Haldor Topsoe A/S, Haldor Topsøes Allé 1, 2800 Kgs, Lyngby, Denmark \\ ${ }^{\mathrm{b}}$ Department of Energy Conversion and Storage, Technical University of Denmark, Ris $\phi$ Campus, Frederiksborgvej 399, 4000, Roskilde, Denmark
}

\section{ART ICLE INFO}

\section{Keywords:}

Infiltration

Nickel

Gd-doped ceria

Carbon

Repair

Lifetime

\begin{abstract}
A B S T R A C T
The solid oxide cell (SOC) could play a vital role in energy storage when the share of intermittent electricity production is high. However, large-scale commercialization of the technology is still hindered by the limited lifetime. Here, we address this issue by examining the potential for repairing various failure and degradation mechanisms occurring in the fuel electrode, thereby extending the potential lifetime of a SOC system. We successfully infiltrated the nickel and yttria-stabilized zirconia cermet electrode in commercial cells with Gd-doped ceria after operation. By this method we fully reactivated the fuel electrode after simulated reactant starvation and after carbon formation. Furthermore, by infiltrating after $900 \mathrm{~h}$ of operation, the degradation of the fuel electrode was reduced by a factor of two over the course of $2300 \mathrm{~h}$. Lastly, the scalability of the concept is demonstrated by reactivating an 8-cell stack based on a commercial design.
\end{abstract}

\section{Introduction}

The solid oxide cell (SOC) is a promising device for the conversion of intermittently produced electricity into storable chemical energy by electrolysis of $\mathrm{H}_{2} \mathrm{O}$ and/or $\mathrm{CO}_{2}$ [1]. The technology still faces challenges regarding lifetime [2] and capital cost before a large-scale commercialization can take place. Taking advantage of economies of scale requires targeting niche markets initially, such as reduction of $\mathrm{CO}_{2}$ to $\mathrm{CO}$ or biogas upgrading [3]. However, to mitigate degradation and failure mechanisms and thereby increase lifetime, significant efforts in materials and surface science are still required.

The concept of infiltrating nano-sized particles to increase surface area or supply electronic or ionic conductivity to the electrodes was initially considered to be immensely promising on account of the high performance reported [4]. Infiltration of the oxygen electrode, especially, has been intensely studied [5-7]. Efforts are also being made to develop alternative fuel electrode structures or to modify the classical nickel/yttria-stabilized zirconia (Ni-YSZ) electrode [7-9]. Some success has been obtained, especially in terms of increased robustness (carbon formation tolerance, redox tolerance, poisoning tolerance), but the concept has not been embraced by solid oxide cell producers. The $\mathrm{Ni}$-YSZ electrode is still cost-effective compared to alternative lab-scale electrodes and is currently employed by nearly every commercial SOC producer [2]. For the Ni-YSZ electrode, the infiltration process is somewhat complicated by the requirement of $\mathrm{NiO}$ reduction to allow room for the infiltrated material. Even so, it would be beneficial in paving the way for a commercial breakthrough to enhance the performance or robustness of this well-known cermet, ideally without altering the already well-established fabrication process.

One concern related to SOC infiltration that has been raised consistently is whether the improved performance has a lasting effect, and only few studies [10] have reported the performance of infiltrated cells over the course of the required thousands of hours. Another concern is whether the technique is scalable to stack-level. Infiltration on stack level has been achieved before by infiltrating individual non-Ni-YSZ electrodes before assembly [10]. In the collaboration between Topsoe Fuel Cell A/S and DTU Energy, a Ni-YSZ-based stack was recently infiltrated after assembly [11]. The beneficial effect was most noticeable after infiltration of the oxygen electrode, and that of the Ni-YSZ electrode was negligible. However, except for these recent cases, the typical approach is still to apply the solution with a pipette, in many cases onto a $\mathrm{mm}^{2}$-sized symmetric cell.

Here we have infiltrated commercially sized Ni-YSZ electrodes on both cell and stack level, after assembly. Furthermore, we have applied the concept of infiltration in an unconventional manner, namely to

\footnotetext{
* Corresponding author. Haldor Topsoe A/S, Haldor Topsøes Allé 1, 2800 Kgs, Lyngby, Denmark.

Email address: tlsk@dtu.dk (T.L. Skafte)
} 
mitigate various failure and degradation mechanisms after they have occurred. This contrasts to the typical objective of enhancing the beginning-of-life performance. In the following we thus investigate the concept of reactivating the fuel electrode after detrimental damage such as reactant starvation and carbon formation. Furthermore, we examine the same effect on long-term, steady degradation. Lastly, we explore the possibility of reactivating a severely damaged commercial stack after thousands of hours of operation. We perform the majority of the testing in harsh $\mathrm{CO} / \mathrm{CO}_{2}$ gas atmospheres, relevant for the aforementioned niche application.

\section{Experimental}

Nominally identical planar cells from the same production batch manufactured by Haldor Topsoe A/S were tested as reference cells. The cells have a Ni-YSZ support, a Ni-YSZ active fuel electrode, an YSZ electrolyte, and a strontium and cobalt co-doped lanthanum ferrite (LSCF)/ gadolinium doped ceria (CGO) oxygen electrode with a CGO barrier layer at the interface between the electrolyte and the oxygen electrode. Further details about the cells can be found elsewhere [12]. All cells were laser-cut to $5.3 \times 5.3 \mathrm{~cm}^{2}$ with a $16 \mathrm{~cm}^{2}$ active area. Cells were mounted in either a FuelCon or DTU Energy in-house designed single-cell test rig at DTU Ris $\varnothing$ campus. A corrugated Ni and Au mesh were used for electronic current collection and fuel distribution on the fuel and oxygen side, respectively. A Au foil frame was used as a sealing gasket on the fuel side. The test-house design is described in more detail in Ref. [13]. The cell was heated to $850{ }^{\circ} \mathrm{C}$ while flowing $\mathrm{N}_{2}$, followed by a reduction process of $2 \mathrm{~h}$ of $9 \% \mathrm{H}_{2} / \mathrm{N}_{2}$ and $1.5 \mathrm{~h}$ of $5 \% \mathrm{H}_{2} \mathrm{O} / \mathrm{H}_{2}$.

Repaired or reactivated cells refer to reference cells infiltrated by a CGO solution on the fuel electrode side after degradation occurred. Stoichiometric amounts of Ce- and Gd-nitrate salts were mixed with water and a surfactant (Triton X-100) to obtain the desired $\mathrm{Ce}_{0.8} \mathrm{Gd}_{0.2} \mathrm{O}_{2-\delta}$-phase. A $\mathrm{Cu}$ infiltration solution was made in the same manner. Since the NiO-YSZ fuel electrode must be reduced prior to infiltration, reference cells were reduced as described above and cooled to room-temperature in $9 \% \mathrm{H}_{2} / \mathrm{N}_{2}$. The cells were then carefully removed from the ceramic test house. After infiltration, the material was decomposed in stagnant air at $350{ }^{\circ} \mathrm{C}$ for $0.5 \mathrm{~h}$. Ni oxidation is a risk while heating the already reduced Ni-YSZ electrode in air, but only minor bending of the cells was observed and as will be shown, the performance did not suffer from this treatment. After the heat-treatment, a brittle layer of CGO was left on the surface which was carefully dusted off and the surface was cleaned with ethanol. Such an infiltration and heating process constitutes one infiltration cycle, and is hereon labeled "1xCGO". By measuring the weight gain and knowing the exact dimensions, the approximate volume that the infiltrated material occupies can be estimated. 1xCGO typically yielded 2 vol- $\%$, and the Ni-YSZ electrode have previously been shown to have a post-reduction porosity of $\sim 30$ vol-\%. A few cells underwent more cycles obtaining a higher loading, or with other materials. For instance, a cell infiltrated with one cycle of CGO and 5 cycles of a $\mathrm{Cu}$ solution is here labeled as " $1 \mathrm{xCGO}+5 \mathrm{xCu}$ ". Lastly, the infiltrated cells could be remounted in the test rig and heated to operating temperature in $9 \% \mathrm{H}_{2} / \mathrm{N}_{2}$. Performing the same procedure without infiltrating any material, i.e. cooling to room temperature, heating in stagnant air to $350^{\circ} \mathrm{C}$, and remounting the cell in the test rig, was investigated and it was found that these thermal cycles had no effect on the performance of the cell (Fig. S1).

Electrochemical impedance spectroscopy (EIS) was measured using a Solartron $1252 \mathrm{~A}$ or 1260 and a measurement resistor. The data was corrected with a short-circuit response of the test setup and stray inductance was subtracted using the Kramers-Kronig procedure. The fre- quency range was typically $0.1 \mathrm{~Hz}$ to $1 \mathrm{MHz}$. All analysis was performed using the RavDav software package [14].

Low-voltage scanning electron microscopy (LV SEM) on a Zeiss Supra 35 FE-SEM was used to analyze the loss of $\mathrm{Ni}$ percolation in long-term tested cells, as described in Thydén et al. [15].

An 8-cell stack produced by Haldor Topsoe A/S was operated for $\sim 3000 \mathrm{~h}$ in electrolysis mode with $95 \% \mathrm{CO}_{2}$ as reactant gas and $5 \%$ of either $\mathrm{H}_{2}$ or $\mathrm{CO}$ to avoid Ni oxidation. The Topsoe Stack Platform (TSP) is a state-of-the-art commercial stack design capable of holding up to 75 cells of approximately $110 \mathrm{~cm}^{2}$ active area [16]. Here, a TSP stack was loaded with 8 full-sized cells and wires for voltage measurements were attached to the interconnects between the cells, allowing for iV and EIS measurements on individual repeating units (RU, a cell and an interconnect). Voltage and EIS were measured on individual RUs throughout the test (Fig. S2). After testing, the stack was then infiltrated with one cycle of CGO by "flushing" the manifold compartments. The solution was then pumped out and air pockets were removed by placing the stack in a vacuum enclosure. The stack was calcined at $350^{\circ} \mathrm{C}$ for $1 \mathrm{~h}$ with a small flow of air, similar to how the solution was calcined for the single cells. A microstructural analysis of the infiltrated material using this technique can be found in Kiebach et al. [11].

\section{Results \\ 3.1. Initial performance}

The improvement in performance of infiltrated cells relative to the reference was investigated by means of EIS in Fig. 1a-b and quantified in Fig. 1c-d. Two infiltrated cells are considered here; 1xCGO and 1x$\mathrm{CGO}+5 \mathrm{xCu}$. $\mathrm{Cu}$ was infiltrated in separate cycles and was chosen as an alternative to $\mathrm{Ni}$ with higher carbon formation tolerance reported [17]. The contributions of different components were modelled using 1-D two-channel transmission line models for the two porous electrodes, and 2-D coupled plug-flow models for the combined gas diffusion and conversion for each electrode [18] (Fig. S7). This advanced model will quantify the impedance accurately and physically meaningful parameters can be extracted, but this is beyond the scope of this investigation. It is more time-consuming than the conventional RQ-based fitting models, which will also be used in the remaining part of this study. The improvement in total resistance and polarization resistance is visible in Fig. 1a. Higher resolution in the frequency/time-domain can be obtained by converting the impedance data to the distribution of relaxation times (DRT), as seen in Fig. 1b. The impedance contribution above $1 \mathrm{kHz}$ is ascribed to the fuel electrode electrochemistry (see Fig. S3 and Fig. S4b), and it is clearly seen that the improvement of the total polarization resistance is entirely caused by changes in the fuel electrode. The total area-specific resistance (ASR) contribution of the fuel electrode decreased by a factor of 5 from $80 \mathrm{~m} \Omega \mathrm{cm}^{2}$ to $16 \mathrm{~m} \Omega \mathrm{cm}^{2}$ for the $1 \mathrm{xCGO}+5 \mathrm{xCu}$ cell (Fig. 1c). The relative contribution compared to the total resistance of the cell decreased from $27 \%$ to $5 \%$ (Fig. 1d).

\subsection{Repairing}

Three different examples of repairing damages to the fuel electrode are examined in the following. The first two examples simulate cases where a human or system error causes severely damaging operating conditions, albeit only for a brief amount of time. The third example is a more general case, where constant operating conditions causes mild, constant degradation. Lastly, the concept is demonstrated to work on a larger scale by going from single cell level to an 8-cell stack. 

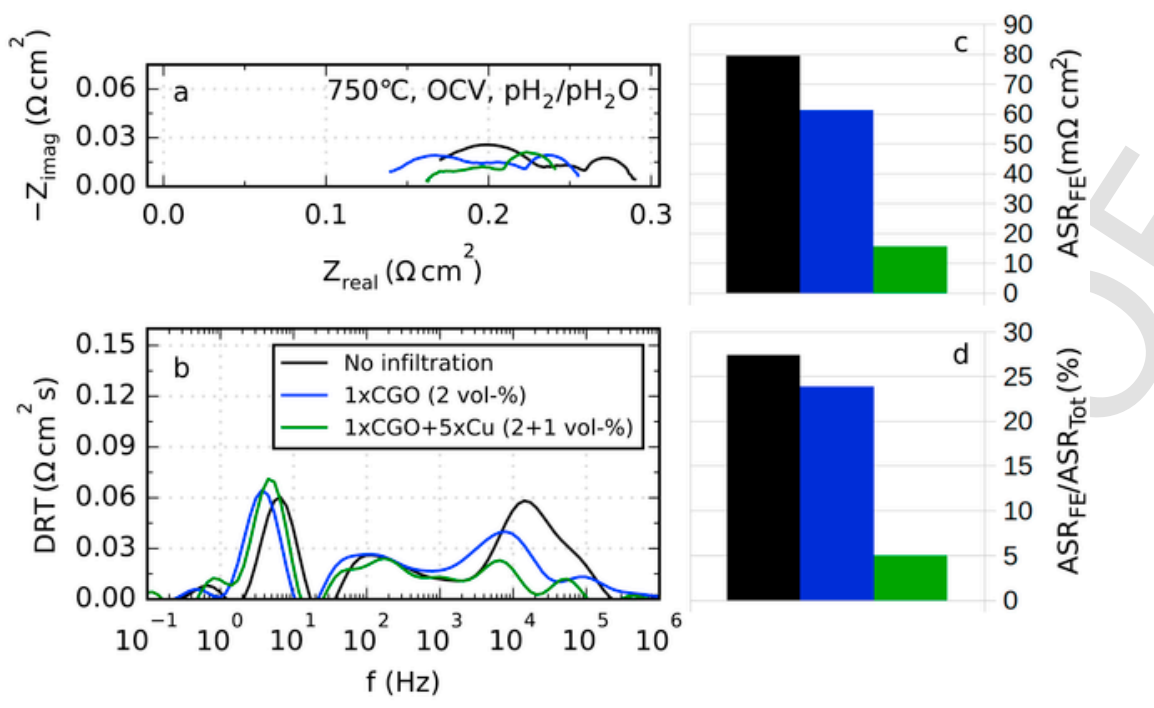

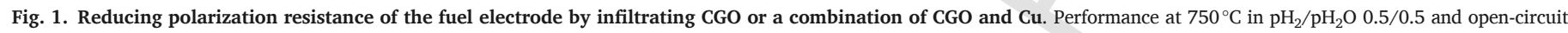

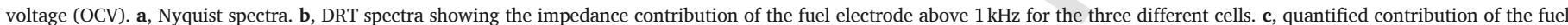
electrode after model fitting. $\mathbf{d}$, the contribution of the fuel electrodes relative to the total ASR.

\subsubsection{Case 1; reactant starvation}

Reactant starvation causes significant, and in some cases fatal, damage to an operating cell. In the case of electrolysis operation, if oxygen ions are not available in the fuel $\left(\mathrm{H}_{2} \mathrm{O}\right.$ or $\left.\mathrm{CO}_{2}\right)$, the fuel electrode material will be reduced. For Ni-YSZ, the oxygen ions in the zirconia lattice will be forced though the electrolyte to the positive electrode leaving zirconium [19]. This was simulated here by operating the cell with an electrolysis current density of $-2 \mathrm{Acm}^{-2}$ for $1 \mathrm{~h}$ with $100 \% \mathrm{H}_{2}$. The cell voltage quickly reached $1.9 \mathrm{~V}$ where it stabilized (Fig. S8), suggesting this to be the potential required for zirconia reduction [19]. The damage to the cell is evident from the voltage by comparing the reference cell to the cell starved of reactants (Fig. 2a). However, if a cell exposed to the same treatment is infiltrated by one cycle of CGO, the voltage increase is limited.

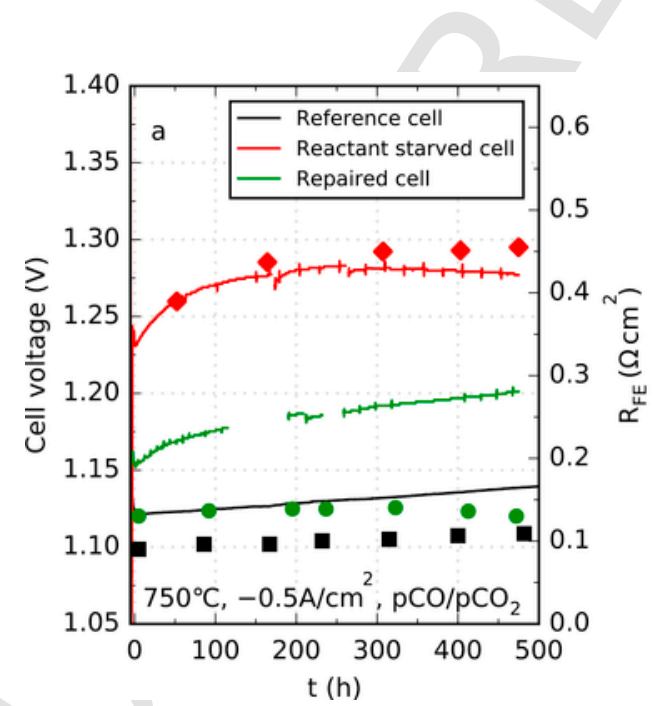

From Fig. $2 \mathrm{~b}$ it is seen that the Ohmic resistance does not change, but the total polarization resistance is clearly affected by the reactant starvation simulation. It is clearly seen from the DRT spectrum (Fig. 2c) that only the fuel electrode is damaged. The low frequency peak $(0.1-1 \mathrm{~Hz})$, which also increases, is mainly ascribed to gas conversion in the fuel electrode (see Supporting Information). By fitting the impedance collected throughout the experiments with a simple L-R-RQ-RQ-RQ-RQ-RQ model (Fig. S9), the contribution of the fuel electrode can be quantified and the result is shown in Fig. 2a on the 2nd $y$-axis. $R_{\mathrm{FE}}$ agrees well with the observed changes of cell voltage, except for the repaired cell. The resistance of the fuel electrode is almost as low as for the reference cell, and the electrode can thus be largely considered restored to the condition it was in prior to the damaging effect occurred. The difference in cell voltage, however, means that some other part of the cell degraded, and the impedance of the oxygen electrode
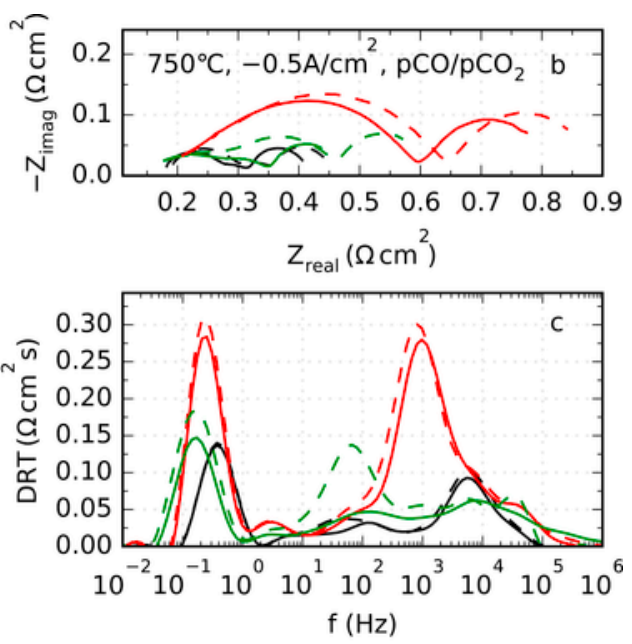

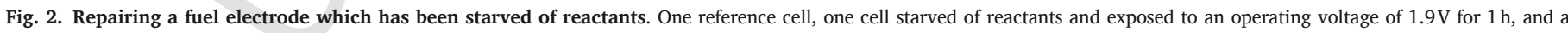

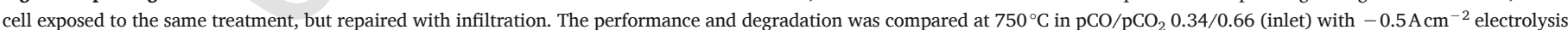

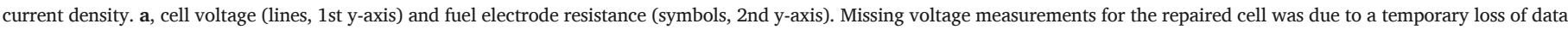

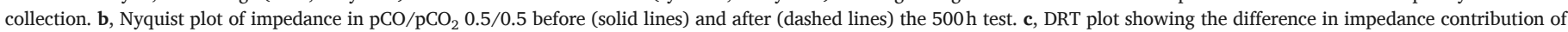
the fuel electrode above $\sim 1 \mathrm{kHz}$ and the increased contribution of the oxygen electrode for the repaired cell at a peak frequency of $\sim 80 \mathrm{~Hz}$. 
was indeed observed to increase (Fig. 2c, frequency range 10-100 Hz). The cause of this was not identified and is not in focus here, but it is noted that the observation could not be reproduced and is therefore deemed coincidental.

\subsubsection{Case 2; carbon deposition}

Another example of a fatal failure mechanism is carbon formation in the Ni-YSZ electrode. Since Ni is an excellent catalyst for carbon formation, this can occur when operating on hydrocarbons or $\mathrm{CO} / \mathrm{CO}_{2}$. Here, the case was simulated by applying a sufficiently high electrolysis current density, so that the local thermodynamic threshold for carbon formation at the electrode/electrolyte interface is crossed. Run-away carbon formation will quickly delaminate the electrode from the electrolyte during electrolysis operation [20-22] which will rapidly destroy the electrode. However, by carefully monitoring the voltage and current density, the amount of carbon, and thus the damage caused, can be controlled [22]. This case thus simulates a system where the gas or current (in the case of fuel cell-mode) supply momentarily fails, causing a small amount of carbon to form inside the electrode. The damage caused is illustrated in the EIS spectrum in Fig. 3. Once again, it is clearly seen that the damage is confined to the fuel electrode in the frequency range above $1 \mathrm{kHz}$ (Fig. 3b). By infiltrating the cell after carbon formation, however, the performance can be restored. In fact, the total fuel electrode polarization resistance is almost exactly identical to that before carbon deposition, i.e. $110 \mathrm{~m} \Omega \mathrm{cm}^{2}$ (Fig. 3c). However, as seen in Fig. 3a and quantified in Fig. 3d, the Ohmic resistance has increased after carbon deposition, which is likely due to electrode|electrolyte delamination, which occurs when carbon deposits at this interface, as mentioned earlier. The extent to which the damage can be repaired thus depends on how much carbon is deposited.

\subsubsection{Case 3; generic degradation}

In the third example we do not consider any specific degradation or failure mechanisms. Instead, we let the cell run under constant conditions and degrade steadily. This will cause degradation of presumably all components in the cell, so we do not expect a full recovery when repairing only the fuel electrode. A reference cell was operated for $2300 \mathrm{~h}$ in $\mathrm{CO} / \mathrm{CO}_{2}$ with a steady degradation rate for the first $1600 \mathrm{~h}$ of $37 \mathrm{mVkh}^{-1}$ and $60 \mathrm{~m} \Omega \mathrm{cm}^{2} \mathrm{kh}^{-1}$ (fuel electrode ASR only). Another cell was operated for approximately $900 \mathrm{~h}$ with a similar degradation rate of $36 \mathrm{mVkh}^{-1}$ and $44 \mathrm{~m} \Omega \mathrm{cm}^{2} \mathrm{kh}^{-1}$ (disregarding the jump at $\mathrm{t}=700 \mathrm{~h}$ caused by $72 \mathrm{~h}$ in $\mathrm{H}_{2} / \mathrm{H}_{2} \mathrm{O}$ at OCV). The cell was then infiltrated and operated for $1300 \mathrm{~h}$ more. The degradation rate dropped to $11 \mathrm{mV} \mathrm{kh}^{-1}$ and $32 \mathrm{~m} \Omega \mathrm{cm}^{2} \mathrm{kh}^{-1}$ (Fig. 4a), i.e. approximately a third of the degradation rate in terms of voltage and half in terms of fuel electrode resistance, compared to the reference. After $2300 \mathrm{~h}$ the fuel electrode resistance of the reference cell is $270 \mathrm{~m} \Omega \mathrm{cm}^{2}$, while the repaired cell is almost half of that; $140 \mathrm{~m} \Omega \mathrm{cm}^{2}$. This can also be seen from the Nyquist and DRT spectra in Fig. 4b-c. The component responsible for the majority of the degradation rate is now the oxygen electrode (Fig. $4 \mathrm{c}, \sim 30 \mathrm{~Hz}$ ). A third cell was infiltrated prior to testing. During the first $500 \mathrm{~h}$, the degradation rate was surprisingly high and comparable to the reference cell, i.e. $40 \mathrm{mVkh}^{-1}$ and $62 \mathrm{~m} \Omega \mathrm{cm}^{2} \mathrm{kh}^{-1}$. Data collection was lost for $500 \mathrm{~h}$, but after $1250 \mathrm{~h}$ of testing, the fuel electrode resistance was lower than for the reference cell. However, the resistance after 1250 $\mathrm{h}$ is identical to the repaired cell after testing for $2350 \mathrm{~h}$. This indicates that there is an additional beneficial effect of infiltrating the cell after it has been tested for a certain period of time, compared to infiltrating before starting testing.

The peak frequency of the infiltrated electrodes have shifted to significantly lower frequency (from $\sim 5 \mathrm{kHz}$ to $\sim 250 \mathrm{~Hz}$ ) and starts overlapping with the oxygen electrode peak $(\sim 25 \mathrm{~Hz})$. This makes it difficult to distinguish between the two in the Nyquist plot, but they can still be separated in the DRT plot and thus in the fitting of the data. A more in-depth analysis of the evolution of the DRT spectra for the three cells can be seen in Fig. S10.

The Ohmic resistance did not change significantly during the tests. This agreed with the relatively small loss of Ni percolation after testing (Fig. S11), which will otherwise result in an additional porous electrolyte layer. Under these conditions, the degradation is thus not entirely due to loss of $\mathrm{Ni}$ percolation as may be the case in demanding steam electrolysis operation with poor Ni-YSZ microstructure [23]. It is however interesting to note that some percolation near the electrode electrolyte interface is in fact lost, most notably for the reference cell (Fig. S11b), which suggests that a lower overpotential (Fig. S11c, the repaired cell) leads to less Ni percolation loss [24]. Importantly humidity does not play a role here, since the cells were operated without $\mathrm{H}_{2}$ and $\mathrm{H}_{2} \mathrm{O}$. Ni migration was not analyzed, but qualitatively does not appear to have occurred.
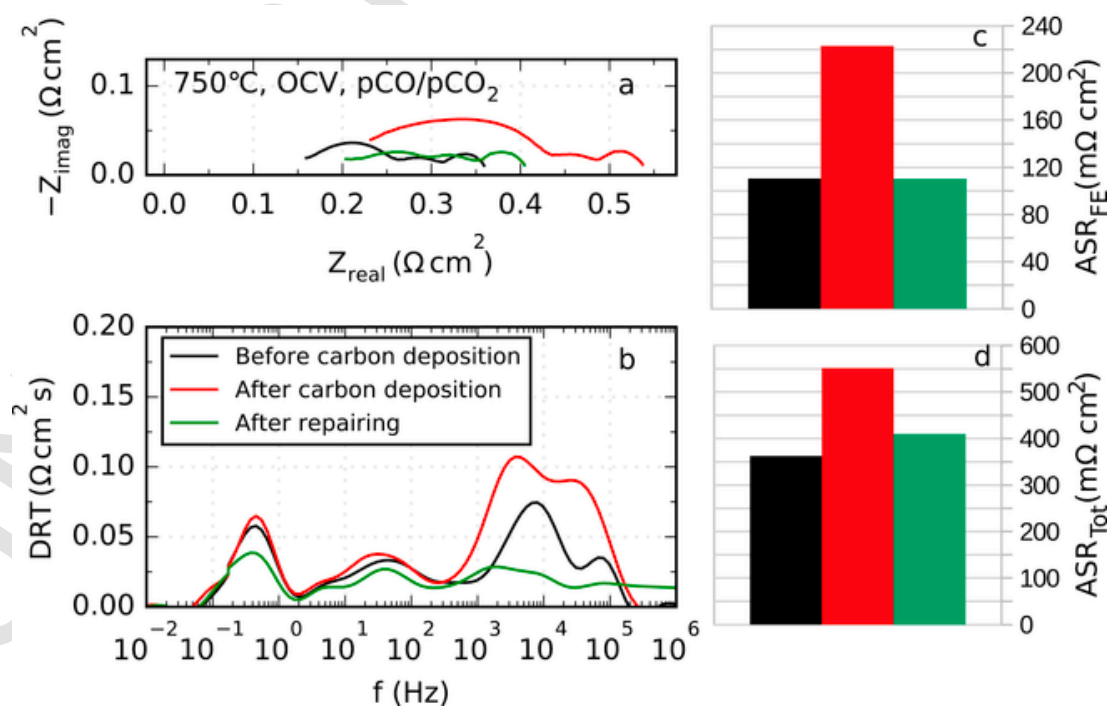

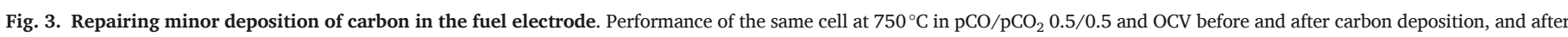

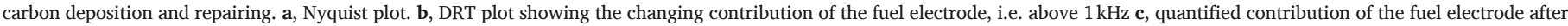
model fitting. d, quantified total resistance of the cell after model fitting. 

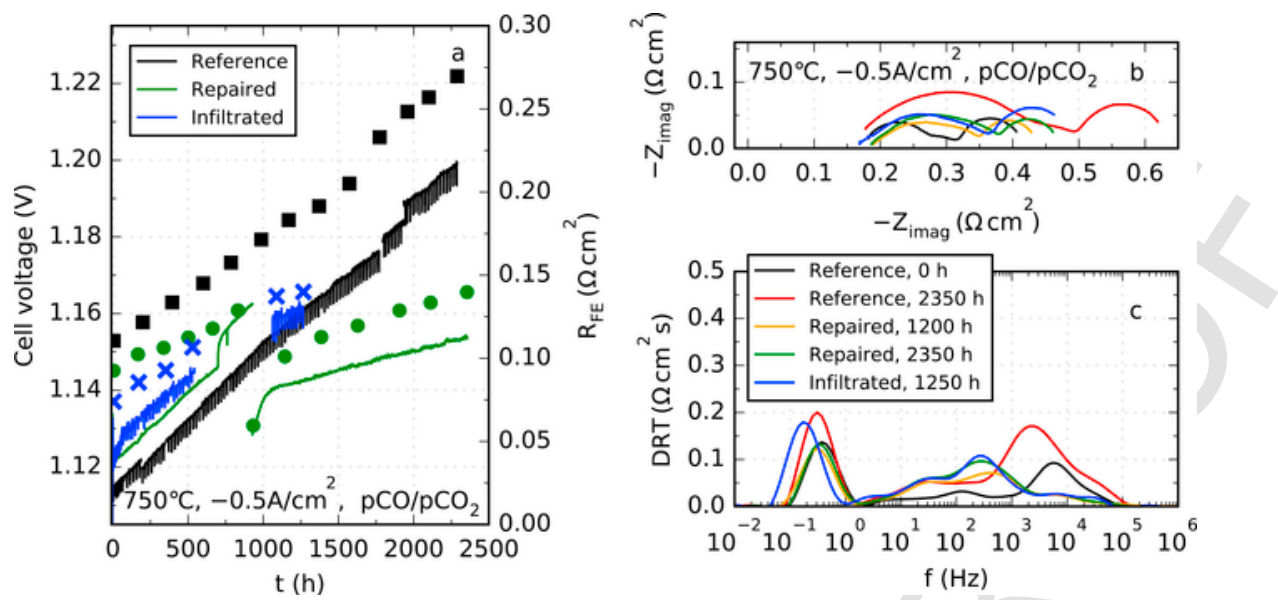

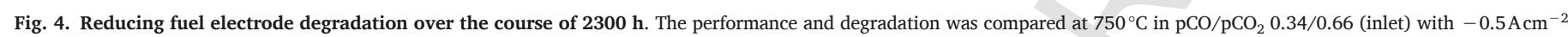

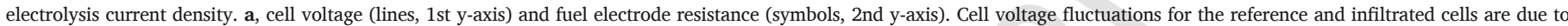

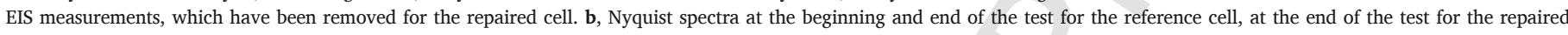

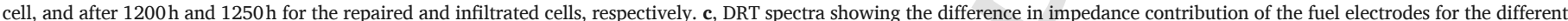

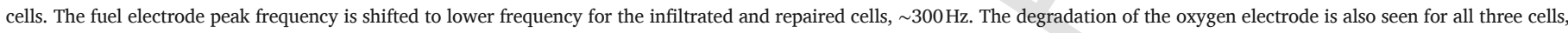
at $\sim 100 \mathrm{~Hz}$ for the beginning of the reference test and shifted to $\sim 25 \mathrm{~Hz}$ at the end of the tests.

\subsection{Stack level tests}

To illustrate the applicability of the concept to the technology in general, the method was scaled up to stack level. The lifetime of the stack is not the focus here and will be published elsewhere, but a brief description follows. The RUs degraded steadily and the average cell voltage had increased with $\sim 100 \mathrm{mV}$ during the test, except for the first three RUs. Some of the suspected main degradation mechanisms were sulfur poisoning by contaminants in the $\mathrm{CO}$ gas and minor carbon formation. Furthermore, a number of significant events causing interruptions in the test occurred and these may affect the degradation as well, i.e. pollution of the air to the oxygen electrode with oil, power supply failure, $\mathrm{CO}_{2}$ gas supply failure and carbon formation in the surrounding tubing.

After the long-term test, the stack was infiltrated with one cycle of CGO. Voltages obtained in SOFC mode $\left(+0.2 \mathrm{~A} \mathrm{~cm}^{-2}\right)$ with $\mathrm{H}_{2} / \mathrm{N}_{2}$ were either fully restored or even higher than when the test was started (Fig. 5). The voltage of the most degraded cells improved the most, and the voltage spread decreased significantly (Fig. S12).

\section{Discussion}

The initial performance gain of infiltration is commonly reported. We confirmed this observation as we were able to reduce the resistance of the fuel electrode fivefold. Next, we turned our attention to another concept. The ability to repair the cells after near-death incidents, as shown here in the first two examples, could prove to be a useful tool when operating a complex system with many more components than just the SOC stack. The supply of gases or the current supply could be unintentionally interrupted for various reasons, but if the disruption is of short duration on the timescale of minutes or a few hours, we have shown here that the cells are capable of recovering from the damaging effects that can occur, such as reactant starvation or carbon formation. It is likely that any damage that causes minor delamination between the Ni and YSZ particles can be recovered from by this method (Fig. 6). Furthermore, by infiltrating a mixed ionic and electronic conductor (MIEC) with electrocatalytic properties, such as CGO, the reaction zone can be extended. Thus, not only is the delamination repaired, the electrode also gains a larger electrocatalytically active reaction

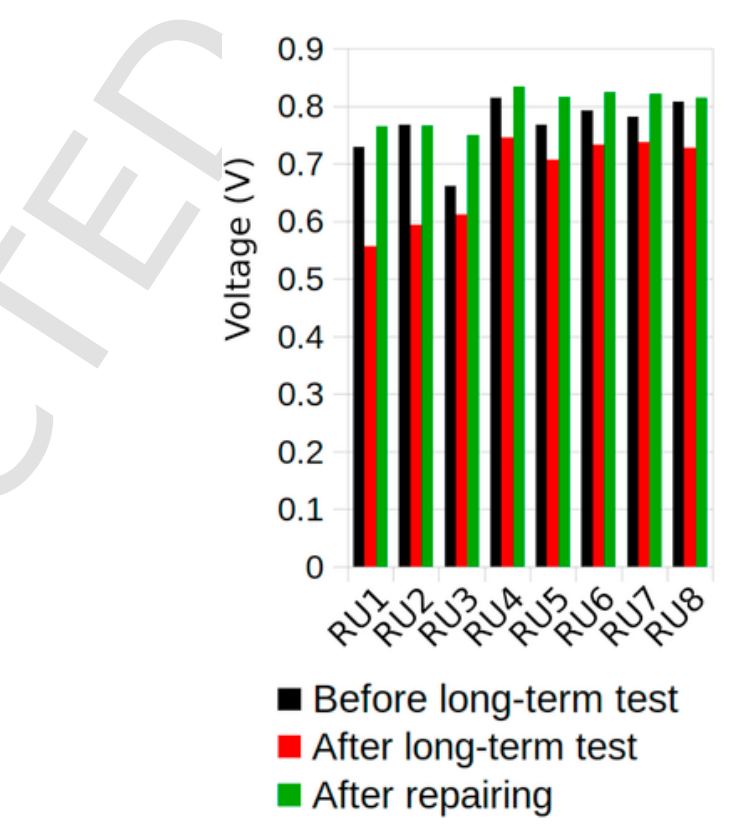

Fig. 5. Regaining voltage by reactivating a SOC stack. Individual voltage measurements for each $\mathrm{RU}$ at $700^{\circ} \mathrm{C}$ with $\mathrm{pH}_{2} / \mathrm{pN}_{2} 0.6 / 0.4$ and $0.2 \mathrm{Acm}^{-2}$ (SOFC-mode), before and after a $\sim 3000 \mathrm{~h}$ electrolysis stack test, and after reactivating the stack by means of infiltration.

zone. Upon microstructural inspection of the infiltrated cells after testing, it is observed that the entire electrode is covered by the infiltrated nano-particles, except for the innermost $\sim 10 \mu \mathrm{m}$ (see Fig. S2 in Ref. [22]). Since the innermost $10 \mu \mathrm{m}$ are where most of the reactions take place, it is believed that the performance gain can be further improved by optimizing the viscosity of the solution used for infiltration as well as the porosity of the electrode. We have already shown that the type of material and volume infiltrated play a role in the performance gain (Fig. 1).

A valid concern often raised regarding SOC electrode infiltration is the longevity of the effect. As have been shown by others (see references in Ref. [7]), the infiltrated material tends to agglomerate with time and the performance gain is invalidated. Here we show that, un- 

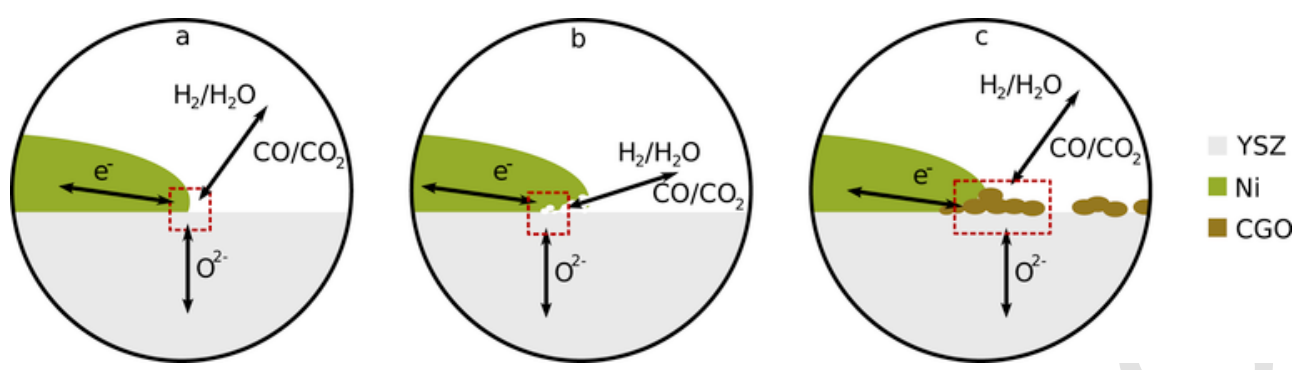

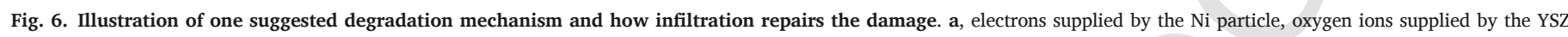

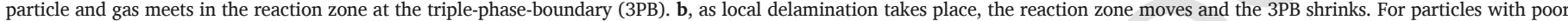

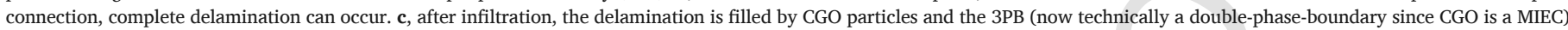
increases again.

der the conditions used here, infiltration may indeed improve the cell performance over the course of several thousand hours, especially when the electrode is infiltrated after stabilization of the microstructure has taken place. The preliminary results presented here certainly warrants further investigation.

The second valid concern against infiltration is whether the technique is scalable. Here we take the first step towards proving the scalability by infiltrating an 8-cell stack based on a commercial full-sized stack design. We believe that by combining many decades of experience from infiltration in the field of heterogeneous catalysis and a stack infiltration technique such as that developed by DTU and Haldor Topsoe A/ $S$ [11], it is possible to cost-effectively infiltrate full-sized stacks. Here, the concept of reactivating the fuel electrode was shown to be transferable from cell to stack level. The individual cell performance based on voltage measurements was regained after $\sim 3000 \mathrm{~h}$ of testing with various degradation mechanisms and many unintended systemic failures. Much remain to be investigated, however, and this experiment merely establish the validity of the method on stack-level. Higher control of the specific degradation mechanisms must be obtained to gain more knowledge of the effect, the reactivated stack should be further tested after infiltration, and naturally the method should be scaled up to full-sized commercial stack- or even system-level.

\section{Conclusions}

In the present study we have demonstrated a novel concept of repairing lifetime limiting mechanisms in SOCs. Three case-studies were considered as proof-of-concept on commercial cells. Damages incurred by simulated reactant starvation and carbon formation were fully repaired and the performance of the electrode was entirely restored. The effect was shown to be lasting for $500 \mathrm{~h}$ and we have no reason to believe that this would change with additional test time. The third case-study was to examine the effect on generic steady-state degradation. By allowing the microstructure to first stabilize, the degradation of the infiltrated electrode was shown to be significantly reduced over the course of $2300 \mathrm{~h}$. Lastly, the method was scaled up to stack level with similar positive effects.

Much still remain to be investigated and, as we also demonstrated here, with only minor optimization the performance gain can be even greater. The basic procedure established here demonstrate renewed potential for SOC electrode infiltration and the possibility of optimizing the traditional Ni-YSZ cermet.

\section{Funding}

This work was supported by Haldor Topsoe A/S, Innovation Fund Denmark and ForskEL project "Towards Solid Oxide Electrolysis Plants in 2020" [grant number 2015-1-12276].

\section{Acknowledgments}

The authors would like to thank colleagues at both the Technical University of Denmark, Department of Energy Conversion and Storage, especially H. Henriksen and J. Høgh, and at Haldor Topsoe A/S, especially A. Pomiklo and J. Hvass.

$\begin{array}{ll}\text { Glossary } & \\ \text { SOC } & \text { Solid oxide cell } \\ \text { Ni-YSZ } & \text { Nickel and yttria-stabilized zirconia } \\ \text { DTU } & \text { Technical University of Denmark } \\ \text { LSCF } & \text { Strontium and cobalt co-doped lanthanum ferrite } \\ \text { CGO } & \text { Gadolinium doped ceria } \\ \text { EIS } & \text { Electrochemical impedance spectroscopy } \\ \text { LV SEM } & \text { Low-voltage scanning electron microscopy } \\ \text { TSP } & \text { Topsoe stack platform } \\ \text { RU } & \text { Repeating unit } \\ \text { DRT } & \text { Distribution of relaxation times } \\ \text { ASR } & \text { Area specific resistance } \\ \text { OCV } & \text { Open-circuit voltage } \\ \text { MIEC } & \text { Mixed ionic and electronic conductor }\end{array}$

\section{Appendix A. Supplementary data}

Supplementary data related to this article can be found at https:// doi.org/10.1016/j.jpowsour.2018.01.021.

\section{References}

[1] C. Graves, S.D. Ebbesen, M. Mogensen, K.S. Lackner, Sustainable hydrocarbon fuels by recycling $\mathrm{CO}_{2}$ and $\mathrm{H}_{2} \mathrm{O}$ with renewable or nuclear energy, Renew. Sustain. Energy Rev. 15 (2011) 1-23.

[2] T.L. Skafte, J. Hjelm, P. Blennow, C. Graves, Quantitative review of degradation and lifetime of solid oxide cells and stacks, In: EFCF 2016 Proceedings, 2016, pp. $8-26$.

[3] J.B. Hansen, Solid oxide electrolysis - a key enabling technology for sustainable energy scenarios, Faraday Discuss 182 (2015) 9-48.

[4] S.P. Jiang, A review of wet impregnation - an alternative method for the fabrication of high performance and nano-structured electrodes of solid oxide fuel cells, Mater. Sci. Eng. A 418 (2006) 199-210.

[5] J.M. Vohs, R.J. Gorte, High-performance SOFC cathodes prepared by infiltration, Adv. Mater. 21 (2009) 943-956.

[6] D. Ding, X. Li, S.Y. Lai, K. Gerdes, M. Liu, Enhancing SOFC cathode performance by surface modification through infiltration, Energy Environ. Sci. 7 (2014) 552-575.

[7] S.P. Jiang, Nanoscale and nano-structured electrodes of solid oxide fuel cells by infiltration: advances and challenges, Int. J. Hydrogen Energy 37 (2012) 449-470.

[8] R.J. Gorte, J.M. Vohs, Nanostructured anodes for solid oxide fuel cells, Curr. Opin. Colloid Interface Sci. 14 (2009) 236-244.

[9] Z. Liu, B. Liu, D. Ding, M. Liu, F. Chen, C. Xia, Fabrication and modification of solid oxide fuel cell anodes via wet impregnation/infiltration technique, J. Power Sources 237 (2013) 243-259. 
[10] M.C. Verbraeken, B. Iwanschitz, E. Stefan, M. Cassidy, U. Weissen, A. Mai, J.T.S Irvine, Short stack and full system test using a ceramic a-site deficient strontium titanate anode, Fuel Cell. 15 (2015) 682-688.

[11] R. Kiebach, P. Zielke, J.V.T. Høgh, K. Thydén, H.-J. Wang, R. Barford, P.V. Hendriksen, Infiltration of SOFC stacks: evaluation of the electrochemical performance enhancement and the underlying changes in the microstructure, Fuel Cell. 16 (2016) 80-88.

[12] P. Hjalmarsson, X. Sun, Y.-L. Liu, M. Chen, Influence of the oxygen electrode and inter-diffusion barrier on the degradation of solid oxide electrolysis cells, J. Power Sources 223 (2013) 349-357.

[13] J.C. Njodzefon, Electrode Kinetics and Gas Conversion in Solid Oxide Cells, Ph.D. thesis Technical University of Denmark, 2015,

[14] C. Graves, RAVDAV Data Analysis Software, Version 0.9.8, 2015.

[15] K. Thydén, Y.L. Liu, J.B. Bilde-Sørensen, Microstructural characterization of SOFC $\mathrm{Ni}$-YSZ anode composites by low-voltage scanning electron microscopy, Solid State Ionics 178 (2008) 1984-1989.

[16] J. Rass-Hansen, P. Blennow, T. Heiredal-Clausen, R. Küngas, T.H. Nørby, S. Primdahl, Topsoe Stack Platform (TSP) - a robust stack technology for solid oxide cells, In: EFCF 2016 Proceedings, 2016, pp. 320-326.

[17] V. Duboviks, M. Lomberg, R.C. Maher, L.F. Cohen, N.P. Brandon, G.J. Offer, Carbon deposition behaviour in metal-infiltrated gadolinia doped ceria electrodes for simulated biogas upgrading in solid oxide electrolysis cells, J. Power Sources 293 (2015) 912-921.

[18] C. Graves, J. Hjelm, Advanced impedance modeling of solid oxide electrochemical cells, In: EFCF 2016 Proceedings, 2014, pp. 1-12.

[19] K.V. Hansen, M. Chen, T. Jacobsen, K. Thydén, S.B. Simonsen, S. Koch, M.B. Mogensen, Effects of strong cathodic polarization of the Ni-YSZ interface, J. Electrochem. Soc. 163 (2016) F1217-F1227.

[20] Y. Tao, S.D. Ebbesen, M.B. Mogensen, Carbon deposition in solid oxide cells during co-electrolysis of $\mathrm{H}_{2} \mathrm{O}$ and $\mathrm{CO}_{2}$, J. Electrochem. Soc. 161 (2014) F337-F343.

[21] Y. Tao, S.D. Ebbesen, W. Zhang, M.B. Mogensen, Carbon nanotube growth on nanozirconia under strong cathodic polarization in steam and carbon dioxide, ChemCatChem 4000 (2014) 1220-1224.

[22] T.L. Skafte, P. Blennow, J. Hjelm, C. Graves, Carbon deposition and sulfur poisoning during $\mathrm{CO}_{2}$ electrolysis in nickel-based solid oxide cell electrodes, J. Power Sources 373 (2018) 54-60.

[23] A. Hauch, K. Brodersen, M. Chen, M.B. Mogensen, Ni/YSZ electrodes structures optimized for increased electrolysis performance and durability, Solid State Ionics 293 (2016) 27-36.

[24] M.B. Mogensen, A. Hauch, X. Sun, M. Chen, Y. Tao, S.D. Ebbesen, K.V. Hansen, P.V. Hendriksen, Relation between Ni particle shape change and Ni migration in Ni-YSZ electrodes - a hypothesis, Fuel Cell. 17 (2017) 434-441. 